Matematikai Közlemények

VIII. kötet, 2020

doi:10.20312/dim.2020.02

\title{
Nemszerkeszthető Johnson-poliéderek számítógépes modellezése dinamikus geometriai módszerekkel
}

\author{
Talata István \\ Óbudai Egyetem, \\ Ybl Miklós Építéstudományi Kar, Budapest, \\ talata.istvan@ybl.uni-obuda.hu
}

\begin{abstract}
ÖSSZEFOGLALÓ. Vannak olyan, csak szabályos sokszöglapok által határolt konvex nemuniform poliéderek, melyek nem modellezhetők euklidészi típusú szerkesztéssel (a körzővel és vonalzóval történő síkbeli szerkesztés 3-dimenziós analogonjával). Dinamikus geometriai módszerek alkalmazásával azonban tetszőleges pontossággal modellezhetők ezek a poliéderek: minden ilyen poliéderhez megszerkeszthető egy olyan paraméteres, számítógépes poliédermodell, amely egy egyparaméteres poliédercsalád modellje, és egy bizonyos paraméterérték esetén az adott, szabályos sokszöglapokkal határolt poliéderrel egyezik meg, valamint a paraméterérték a szükséges pontossággal beállítható úgy, hogy a hozzá tartozó virtuális modell tetszőleges elöírt mértékben közelítse a kívánt poliédert.
\end{abstract}

\begin{abstract}
There are convex nonuniform polyhedra bounded only by regular polygonal faces that can not be modeled by a Euclidean construction (using the 3dimensional analogue of a ruler and compass planar construction). However, using methods of dynamic geometry, it can be achieved that such a polyhedron is modeled within arbitrary accuracy: for each such polyhedron, a computer model of a parametric polyhedron can be constructed as the result of Euclidean construction steps, that is the model of a single-parameter polyhedron family, and it is congruent to the given polyhedron for a specific parameter value, having only regular polygonal faces, and the parameter value can be adjusted until it is necessary to achieve the required accuracy of the virtual model for the given polyhedron.
\end{abstract}

\section{Bevezetés}

A 3-dimenziós alakzatok számítógépes modellezésekor lehetőség van geometriai módszerek használatára - ekkor egyszerü alakzatokból kiindulva készítünk összetett modellt, új alakzatok vagy segédalakzatok segítségével (pl. szerkesztőegyenesek, szakaszok, körök, síkok, sokszöglapok, gömbök felhasználásával), és geometriai transzformációk (pl. forgatás, eltolás, tükrözés) alkalmazásával. Ez elegánsabb módszer, mint a másik, amikor matematikai számításokkal elöállított pontkoordináták alapján viszünk fel térbeli pontokat, és azokra illeszkedő alakzatokat készítünk (pl. egy poliéder modellje eképp is elkészíthető).

A geometriai modellezési módszerek előnye, hogy a modellezett alakzat bizonyos tulajdonságait nem kell külön ellenőrizni, mert a konstrukcióból következnek: egyes esetekben például egy test szimmetriáit felhasználva forgatásokkal és tükrözésekkel készíthető el a modell

KULCSSZAVAK. Johnson-poliéder, dinamikus geometria, számítógépes modellezés, szerkeszthetőség. KEYWORDS. Johnson solid, dynamic geometry, computer modeling, Euclidean construction. 
egy része, ezért a szimmetria igazolásához nem kellenek további számítások. A valódi modellezést is szimulálhatjuk geometriai módszerekkel: például amikor egy poliéder felületét, vagy annak egy részét a síkba kiterített laphálójából, lapok felhajtásával készítjük el, akkor ez úgy modellezhető geometriai módszerekkel, hogy egy-egy lapot forgatunk ez másik lappal közös éle mentén, és gyakran még a forgatás szöge is megszerkeszthető (ld. az 1. ábrát).
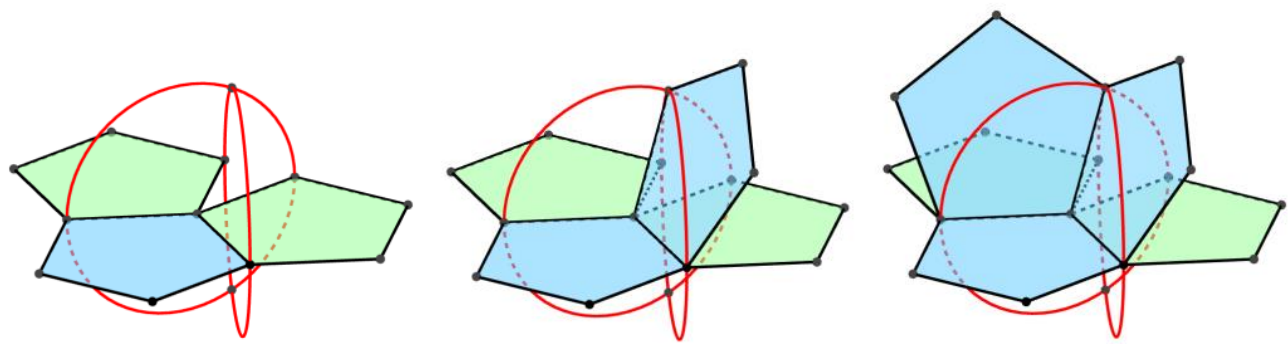

1. ábra. Szabályos dodekaéder egyik csúcsánál találkozó ötszöglapok elkészítése forgatásokkal

Szoftverekkel a 3-dimenziós térbeli geometriai szerkesztések többnyire csak euklidészi típusú térbeli szerkesztésekként (a körzővel és vonalzóval történő síkbeli szerkesztések 3-dimenziós analogonjaként) végezhetők el, síkokkal, gömbökkel, térbeli egyenesekkel, térbeli körökkel dolgozva, vagy olyan parancsokat alkalmazva, amelyek esetén a szerkesztés ilyen térelemekre vezethető vissza (pl. sokszöglapokat, szakaszokat, köríveket is bemeneti térelemként elfogadó parancsok esetén).

Ezért, ha a szerkesztési müveleteink csak az elözőleg megszerkesztett alakzatokon alapulnak, akkor pontosan olyan koordinátájú pontok szerkeszthetök meg ilyen módszerekkel, mint a szokásos síkbeli, körzővel és vonalzóval történő szerkesztésekkor. Ennek következménye, hogy ha egy poliéder euklidészi szerkesztése lehetséges, akkor a poliéder bármely két csúcsának a távolsága, és bármely két lapszögének a koszinusza olyan valós szám kell, hogy legyen, melyet a racionális számok feletti másodrendű testbővítések véges sokszori egymás után alkalmazásával kapunk meg. Ezért például egy ilyen mennyiséghez tartozó racionális együtthatós minimálpolinom fokszáma 2 pozitív hatványa kell, hogy legyen (ez szükséges, de nem elégséges feltétel a szerkeszthetöségre), ld. a 2 . fejezetet a szerkeszthetőségre vonatkozó további részletekért.

A szabályos testek mind szerkeszthetők, az arkhimédészi, félig szabályos testek (ld. [2], [3]) között azonban már találhatók nem szerkeszthetö testek: a pisze kocka és a pisze dodekaéder. A Johnson-poliéderek olyan konvex poliéderek, melyeknek minden lapjuk szabályos sokszög, de csúcsaiknál nem „egyformák” (úgy mondjuk, hogy „nem uniform poliéderek"), azaz van legalább két olyan csúcsuk, melyekre nem található a térnek olyan egybevágósága, mely az egyik csúcsot átviszi a másikba, miközben a poliédert önmagába képezi le. A 92 Johnson-poliéder közül 85 könnyen szerkeszthető (ld. [1], [8], [10]). Van azonban 7 olyan Johnson-poliéder, amely nem szerkeszthető (vagy valószínúleg nem szerkeszthető), ezek a J84-J90 sorszámú poliéderek, ld. a 3. fejezetet további részletekért.

A dinamikus geometriai szoftverek sajátossága, hogy bizonyos fajta paraméteres modellezés is megvalósítható velük, pl. szakaszon vagy körön változtathatjuk egy vagy több pont helyét, vagy egy (esetleg több) olyan paramétert vezethetünk be, amelynek értékeit véges intervallumban, adott lépésközzel változtathatjuk, és az ilyen paraméter(ek) értékének megváltoztatásakor egy adott szerkesztési eljárásban a végeredmény is értelemszerüen frissül és módosul. Ezáltal lehetőségünk van arra, hogy ne kelljen újra és újra elvégezni ugyanazt a szerkesztési eljárást különböző bemeneti paraméterekre, amíg a szerkesztés végeredménye valamely kívánalmaknak meg nem felel, hanem a bemeneti paraméter(ek) változtatásával 
kikísérletezhető, hogy milyen paraméterértékekre lesz az eredmény elég közel a kívánalmakhoz.

A J84-J90 Johnson-poliéderek modellezése során olyan eljárásokat fogunk tudni megadni a 4. és 5. fejezetekben, amelyek mindegyike egyetlen, de az adott poliédertől függően kiválasztott geometriai jelentésü paraméteren alapul.

A továbbiakban feltesszük (hacsak valahol konkrétan másképp nem írjuk), hogy a modellezni kívánt poliéder élei egységnyi hossszúak (így egyszerübben írható le a modellezésünk). Egy lapszög lesz a paraméter mindegyik vizsgált poliéder esetén, és egy olyan poliédermodellt készítünk el térbeli euklidészi szerkesztéssel (felhasználva a paraméter aktuális értékét), amelynek a laphálója megegyezik az adott poliéderével, és néhány éle, ill. lapja kivételével az élei ill. a lapjai egybevágóak az adott poliéderen hozzájuk tartozó élekkel, ill. lapokkal, azaz csak egyetlen vagy esetleg néhány éle nem lesz egységnyi hosszú, és elég sok lapja szabályos sokszög lesz.

A paraméter változtatásakor a poliédermodell alakja folytonosan deformálódik. Ha a modellünket úgy képzeljük, hogy a mindvégig szabályos sokszöglapok merev lemezek, melyek a szomszédos lemezekhez csuklósan kapcsolódnak a közös élek mentén, akkor ennek a csuklós szerkezetnek egy egyparaméteres mozgását kapjuk a paraméter változtatásakor. Egy bizonyos élhosszat figyelünk majd, lesz amikor az egységnél kisebb, és lesz, amikor egységnél nagyobb lesz a hossza. Folytonossági meggondolások alapján valahol fel kell, hogy vegye az egységnyi hosszúságot, és intervallumfelezéssel be tudjuk úgy állítani a paraméter értékét, hogy a kérdéses élhossz egy hibahatárnál közelebb legyen az egységhez (a szoftveres korlátokat is figyelembe véve, a valóságban persze nem tudunk bármekkora pontosságot elérni). Ekkor a poliédermodellünk minden éle a hibahatárnál közelebb lesz az egységhez, és így jó közelítése lesz a modellezni kívánt Johnson-poliédernek.

Végül megmutatjuk, hogy a pisze kocka és pisze dodekaéder arkhimédészi testek esetében is lehetséges hasonló konstrukció, csak akkor a paraméteres modellben a nagyfokú szimmetria miatt elég sok él nem lesz végig egységnyi hosszú a paraméter összes lehetséges értékére, hanem kétféle élhossz lesz, egységnyi élhossz és egy másik élhossz, amelyik értéke változik a paraméter változtatásakor

\section{Szerkeszthetőség a 3-dimenziós térben}

A 3-dimenziós euklidészi tér síkokra és gömbökre épülő szerkesztései a síkbeli, körzővel és vonalzóval történő szerkesztések 3D analogonjai. Feltesszük, hogy kezdetben adott legalább négy olyan pont, amelyek nincsenek egy síkon. A térbeli szerkesztési alaplépések: egy egyenesre nem illeszkedő három pontra illeszthetünk egy síkot; valamint adott ponttal, mint középponttal rendelkezö, és egy adott másik ponton, mint felületi ponton áthaladó gömböt rajzolhatunk (gömbön itt gömbfelületet értünk); továbbá három térelem (síkok vagy gömbök) esetén a metszéspontjaik is megszerkeszthetők, amennyiben véges sok pontban metszik egymást (és nem érintők). A többi, síkokra, gömbökre, egyenesekre és körökre épülő térbeli szerkesztési lépés (pl. adott síkkal párhuzamos sík, vagy adott egyenesre merőleges sík szerkesztése, megszerkesztett síkokon történő egyenesekkel és körökkel történő szerkesztési lépések) mind visszavezethetők a szerkesztési alaplépésekre. A geometriai transzformációk is visszavezethetők szerkesztési alaplépésekre, ha nem engedjük meg akármilyen bemeneti paraméter megadását ( $\mathrm{pl}$. akármekkora forgatási szöget), hanem csak szerkeszthetö mennyiségeket.

Ha csak a térbeli szerkesztési alaplépéseket vizsgáljuk, akkor a három térelem (síkok vagy gömbök) metszéspontjainak a keresése visszavezethető egy egyváltozós, legfeljebb másodfokú egyenlet megoldására. Másrészt, 3 pont által kifeszített sík egyenletének a meghatározásához 
lineáris egyenletrendszert kell megoldani, valamint adott középpontú és felszíni pontú gömb implicit egyenletének a felírása még egyszerübb, így ezekhez a számításokhoz elégséges a 4 alapmüvelet használata.

Emiatt ezekre az euklideszi típusú térbeli szerkesztésekre is igaz (ugyanúgy, mint a síkbeli euklideszi szerkesztésekre), hogy pontosan azok a pontok szerkeszthetők meg, melyek koordinátái a szerkesztés kezdetén adott pontok koordinátáinak véges sok, egymásra épülő másodrendü testbővítés alkalmazásával kaphatók meg. Praktikusan ez azt jelenti, hogy minden koordináta kifejezhető a 4 alapmüvelet és négyzetgyökvonások véges sokszori alkalmazásával.

Másik lehetőség az előbbiek igazolására, ha a Monge-féle két képsíkos ábrázolást tekintjük, amelyet az ábrázoló geometriában elöszeretettel alkalmaznak - ebben sík egy egyenesre nem illeszkedő három pontjával, gömb vetületeivel (körök), egyenes vetületeivel, kör leghosszabb és legrövidebb vetületü átfogóival van ábrázolva (ld. [4]). Ebben az ábrázolási rendszerben a két képsíkon szokásos (körzővel és vonalzóval történő) síkbeli szerkesztésekként végezhetők el a térbeli szerkesztési alaplépések: pl. két sík és egy gömb metszéspontjai nem mások, mint a két sík metszésvonalának (amely egy egyenes) egy gömbbel vett metszéspontjai, amelynek szerkesztése jól ismert az ábrázoló geometriában. Mivel a két képsík a 3-dimenziós tér két koordinátasíkjára vett merőleges vetülete, ezért az azokban felhasznált pontok a 3-dimenziós pontok három koordinátájából két koordináta meghagyásával keletkezett pontok, így tényleg ugyanazok a mennyiségek szerkeszthetők meg síkon körzővel és vonalzóval, mint a térbeli euklideszi szerkesztések során.

Ha csak az origó és a tengelykereszt egységpontjai (azaz a koordinátatengelyeken pozitív irányban egységnyi távolságra levő pontok) adottak kezdetben, akkor az elöbbiekböl következik, hogy minden megszerkeszthető pont mindegyik koordinátája racionális számokat, a 4 alapmüveletet és négyzetgyökvonásokat tartalmazó képletekkel kell, hogy leírható legyen (elnevezés az ilyen számra: „szerkeszthető szám”). A szerkeszthető számok olyan valós számok, melyek minimálpolinomja $2^{k}$ fokú valamely $k$ pozitív egész számra, ld. [6], [9]. (Az $r$ valós szám minimálpolinomja az a legkisebb fokszámú egész együtthatós polinom, melynek az $r$ szám a gyöke.) Fordítva ez nem feltétlenül igaz, azaz, ha egy $r$ valós szám minimálpolinomja $2^{k}$ fokú valamely $k$ pozitív egész számra, akkor $r$ még nem feltétlenül szerkeszthető. Negyedfokú minimálpolinom esetén annak a köbös rezolvense (amely egy harmadfokú polinom) kiszámítható, és ez alapján eldönthető, hogy $r$ szerkeszthető szám, vagy sem. Magasabb kettőhatvány fokszámú $f$ minimálpolinomra már csak annyit tudunk, hogy $r$ pontosan akkor szerkeszthető, ha $\operatorname{Gal}(f: \mathbb{Q})=2^{k}$, valamely $k$ pozitív egész számra, ahol $\operatorname{Gal}(f: \mathbb{Q})$ a Galois-csoportja az $f$ egész együtthatós, a racionális számok halmaza felett irreducibilis polinomnak, ld. [6].

Megjegyezzük, hogy a dinamikus geometriai szoftverekben lehet néhány rajzoló parancs, amely elfogad olyan bemeneti paramétert is, amelyet begépelve nem szerkeszthetö pontot tudunk konstruálni (pl. forgatni bármilyen szögértékkel lehet bizonyos szoftverekben), vagy akár olyan parancs is, amellyel nem szerkeszthető alakzatot hozhatunk létre (pl. szabályos sokszöget akármilyen csúcsszámmal is létrehozhatunk).

A dinamikus geometriai módszerek alkalmazása során, amikor paraméteres poliédermodellt készítünk az adott poliéder közelítésére, ügyelni kell arra, hogy a megfelelő paraméterérték könnyen beállítható legyen, elvileg tetszőleges pontossággal. Erre az egyetlen paraméter használata biztosítja az ideális lehetőséget, mivel ha a modellben vizsgált, változó élhossz hosszabb és rövidebb is lehet az egységnél, akkor folytonossági meggondolás alapján a modell vizsgált élhossza felveszi valamely paraméterértékre az egységnyi hosszúságot, és ilyenkor intervallumfelező eljárással tetszőleges pontossággal megkaphatjuk ezt a paraméterértéket. 

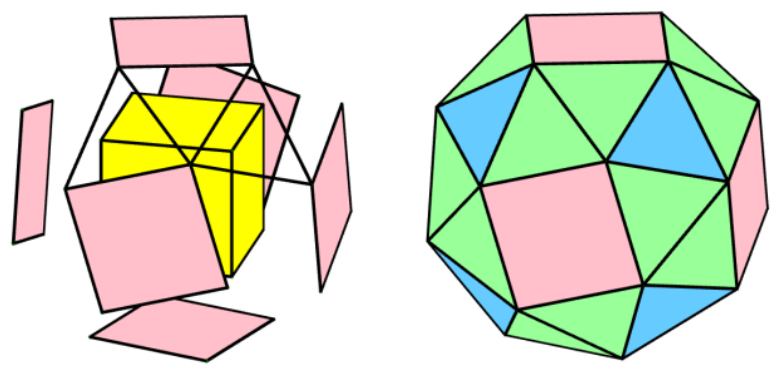

2. ábra. Pisze kocka modellezése kocka lapjainak kifelé történő eltolásával és forgatásával

Azonban egynél több paraméter használata esetén már nem ilyen egyszerü a helyzet. A pisze kocka esete mutatja ezt: azt úgy is lehet modellezni, hogy egy kocka mindegyik lapját a testközéppontból a lapközéppontra állított meröleges félegyenes irányában kifelé toljuk egységesen ugyanakkora távolsággal, és e meröleges félegyenesek, mint tengelyek körül ugyananakkora szöggel el is forgatjuk az eltolt lapokat (ugyanolyan irányítással). Megfelelö eltolási távolság, és megfelelö forgatási szög esetén a keletkezett 6 transzformált négyzetlap konvex burka a pisze kocka, amelyet a négyzetlapokon kívül csupa szabályos háromszöglap határol (ld. a 2. ábrát). De a két paraméternek (forgatási szög, eltolási távolság) az értékét jól kitalálni, megközelíteni eléggé nehézkes, és az sem látszik rögtön, hogy léteznek olyan paraméterértékek, amikor minden háromszöglap szabályos. Tehát kedvezőbb csupán egyetlen paraméter használatára szorítkozni (ld. az 5. fejezet végén a pisze kocka egyparaméteres modellezésének leírását).

\section{Johnson-poliéderek}

Szabályos testek azok a konvex poliéderek, melyeknek lapjai egybevágó szabályos sokszögek, és csúcsai ,egyformák” (azaz egy csúcsát át tudjuk vinni bármelyik másik csúcsába olyan egybevágósági transzformációval, amely a poliédert önmagába képezi le). Az arkhimédészi testek ennek általánosításai, ezeknél nem követeljük meg, hogy egybevágók legyenek a lapok, különböző oldalszámú szabályos sokszögek is lehetnek (a szabályos sokszöglapokból álló egyenes hasábok és antiprizmák végtelen elemszámú családjait nem szokás az arkhimédészi testek közé sorolni), ld. [2], [3]. A szabályos testek és arkhimédészi testek, szabályos prizmák, szabályos antiprizmák együtt alkotják a konvex uniform poliédereket, melyeknek bármely két csúcsukhoz található a térnek olyan egybevágósága, amelyik az egyik csúcsot átviszi a másikba, miközben a poliédert önmagába képezi le, ld. [1].

A Johnson-poliéderek azok a konvex nemuniform poliéderek, melyeknek minden lapjuk szabályos sokszög (ld. [1], [8], [10]). Hasonlóság erejéig 5 szabályos test létezik, 13 arkhimédészi test van, és 92 Johnson-poliéder (ezek J1-J92 sorszámokkal ellátottak a szakirodalomban, a könnyebb hivatkozás végett).

A szabályos testek, és két kivétellel az arkhimédészi testek is modellezhetök euklidészi szerkesztéssel (és persze a szabályos sokszögoldalakkal rendelkező egyenes hasábok, és az antiprizmák is). A két kivétel a pisze kocka és a pisze dodekaéder.

A legtöbb Johnson-poliéder előállítható arkhimédészi testekből, hasábokból és antiprizmákból geometriai alapműveletekkel (csúcsok által meghatározott síkkal való szelés, közös lap mentén egyesítés). A kivételek az ún. elemi Johnson-poliéderek, amelyek a J84-J92 poliéderek. Ezeket szokás a Johnson-poliéderek koronaékszereinek is nevezni, mivel sokkal különlegesebb az alakjuk a többinél. Ezek közül is a J84-86 és J88-J90 Johnson-poliéderek (6 darab) az igazán érdekesek számunkra, mivel a J87 megkapható a J86 poliéderből, ha gúlát 
állítunk az egyik négyzetlapjára, a J91 ésJ 92 poliéderek pedig az ikozidodekaéder (arkhimédészi test) megfelelö felületdarabjainak felhasználásával könnyen megszerkeszthetők.

A J84-J86 és a J88-J90 poliéderek, valamint a pisze kocka és a pisze dodekaéder esetén, azok 2 élhosszú megadásakor (ahogy ez a szakirodalomban található) vannak olyan csúcspárok, melyek távolsága olyan, a 4 alapműveletet és esetleg gyökvonást tartalmazó képlettel adható meg, amely tartalmazza egy legalább harmadfokú, a racionális számok testje felett irreducibilis polinom gyökét is, a racionális számok mellett, melyet nem lehet kiejteni a képletböl ekvivalens átalakításokkal (ld. [2], [3]). Azokban az esetekben, amikor ennek a polinomnak fokszáma nem kettőhatvány, akkor rögtön adódik, hogy a poliéder nem szerkeszthetö (ld. [1]), amikor azonban kettőhatvány (ez a J86 és J88 poliéderek esetén áll fenn), akkor további meggondolások szükségesek ahhoz, hogy belássuk ezeknek a távolságoknak a nemszerkeszthetőségét, és így a hozzájuk tartozó poliédereknek is a nemszerkeszthetőségét. A J86 Johnson-poliéder esetében található két olyan csúcs, melynek távolsága egy negyedfokú $p(x)$ polinom $r_{1}$ gyökének a kétszerese, és $p(x)$ köbös rezolvensét vizsgálva kijön, hogy annak nincs racionális gyöke, ezért $r_{1}$ nem szerkeszthető (ld. [8], [9], [10]). A J88 Johnson-poliéder esetében pedig található két olyan csúcs, melynek távolsága egy 16-odfokú $q(x)$ polinom $r_{2}$ gyökének a négyszerese, amelyről sejthetö, hogy nincs szerkeszthető gyöke (már csak azért is valószínű ez, mert ha ilyesmi ismert lenne, akkor a szakirodalomban gyökös képletekkel adnák meg a J88 poliéder csúcsainak a koordinátáit, de jelenleg nem ez a helyzet), ám a szerző jelenleg nem tudja igazolni a nemszerkeszthetőséget, így a J88 Johnson-poliéder nemszerkeszthetőségét csak sejti (ld. [6], [8], [10]).

\section{A Sphenocorona (J86) modellezése}

Ebben a fejezetben leírjuk a J86 poliéder számítógépes modellezésének a lépéseit. A két szomszédos egységnyi élhosszú négyzetlap hajlásszögét választjuk a modell $\alpha$ paraméterének. Megszerkesztünk egy függőleges helyzetü egységnyi élhosszú négyzetet, és azt a felső $A_{1} A_{2}$ éle, mint tengely körül elforgatjuk mindkét irányba $\alpha / 2$ nagyságú szöggel. A $B_{1}, A_{1}, C_{1}$ csúcsok a két négyzetlap uniójának egyik felén helyezkednek el.
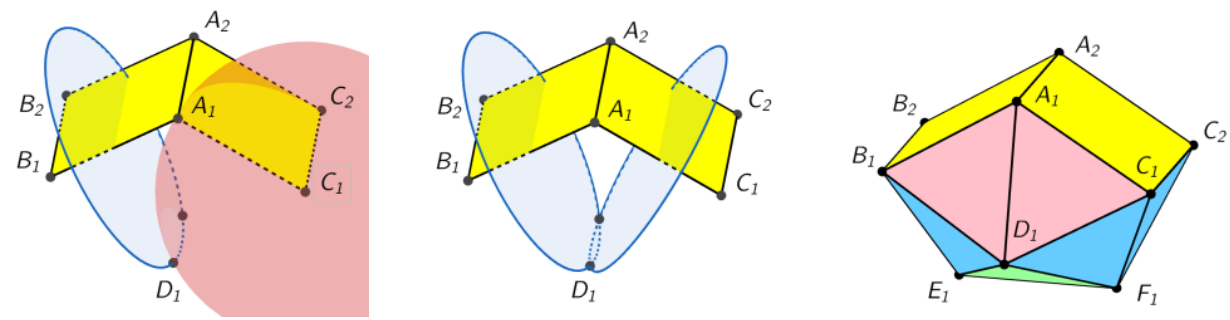

3. ábra. A sphenocorona (J86) szerkesztése

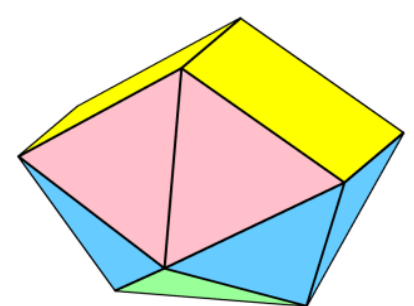

4. ábra. Sphenocorona (J86) 
Szerkesszük meg azt a $D_{1}$ csúcsot, amely egységnyi távolságra van ettől a három csúcstól. Ez három egységgömb metszéspontja lesz (az a metszéspont a két lehetőség közül, amelyik a konvex poliéder csúcsa lehet). Mivel tipikusan nincs három alakzat metszéspontjára parancs a dinamikus geometriai szoftverekben, először két gömb metszésvonalát, azaz egy körvonalat készítsünk, majd azt messük el a harmadik gömbbel (egy másik alternatíva, hogy egy másik gömbpár metszésvonalát - ami szintúgy kör - is elkészítjük, és a két körvonal metszéspontjai közül választjuk ki a megfelelö $D_{1}$ pontot). A $B_{2}, A_{2}, C_{2}$ átellenes csúcshármashoz hasonlóan szerkesszük meg a $D_{2}$ csúcsot. Ezután a $B_{2}, B_{1}, D_{1}$ csúcshármashoz szerkesszük meg azt az $E_{1}$ csúcsot, amely egységnyi távolságra van ettől a három csúcstól, végül a $D_{1}, A_{1}, A_{2}$ csúcshármashoz szerkesszük meg az ezektől a csúcsoktól rendre egységnyi távolságra levő $F_{1}$ csúcsot. Ezzel elkészült a poliédermodell 10 csúcsa. Az egyes csúcsok szerkesztésekor szükség esetén az $\alpha$ paraméter értékén (amely a két négyzetlap által bezárt szög) módosítanunk kell, hogy a három gömb metszete ne legyen üres halmaz (azaz két gömb metszésvonala - ami kör - belemessen a harmadik gömbbe). A két lehetséges metszéspont közül mindig azt kell kiválasztanunk a poliéder csúcspontjának, amelyik biztosítja azt, hogy konvex poliédert kapjunk. A szerkesztés menete a 3. ábrán követhető végig, ahol a $D_{1}$ csúcs kétféleképp történő szerkesztését illusztráltuk, valamint a poliéder csúcsainak a szerkesztésbeli jelölésekkel történő felcímkézése látható. A J86 poliédert pedig a 4. ábra illusztrálja.

A csúcsok szerkesztése közben, akár az egyes csúcsok elkészülte után rögtön elkészíthetjük az ezekre illeszkedő olyan háromszöglapokat, melyeknek az összes csúcsa már megszerkesztett. A poliédermodellünk mindegyik éle egységnyi hosszúságú, kivéve az $E_{1} F_{1}$ élt, és így a modell mindegyik háromszöglapja szabályos háromszög, kivéve a $D_{1} E_{1} F_{1}$ és $D_{2} E_{1} F_{1}$ háromszöglapokat.

Úgy is felfoghatjuk ezt a modellt, hogy nem egy egész poliéderfelületet tekintünk, hanem a $D_{1} E_{1} F_{1}$ és $D_{2} E_{1} F_{1}$ lapokat és az $E_{1} F_{1}$ élt kivesszük a modell poliéderfelületéből: ekkor a virtuális modellünk megfelel egy olyan valóságos modellnek, amelyben a két négyzetlap és a maradék tíz háromszöglap merev lemezek, és a közös éleiknél csuklósan csatlakoznak egymáshoz. Ennek a csuklós szerkezetnek a konvexitás feltétele melletti lehetséges mozgásait adja a paraméteres modellünk.

Az $\alpha$ paraméter értékének változtatásakor a modell alakja változik, méghozzá úgy, hogy amikor $\alpha$ értéke növekszik, akkor az $E_{1} F_{1}$ élhossz is növekszik ( $\alpha$ értéke persze csak egy bizonyos intervallumon belül változhat, hogy a korábban szerkesztett csúcspontok, melyek rendre három gömb metszéspontjai, létezzenek). Mivel van olyan $\alpha$ paraméterérték, melyre az $E_{1} F_{1}$ élhossz egységnél rövidebb, és van olyan $\alpha$ paraméterérték is, melyre az $E_{1} F_{1}$ élhossz egységnél hosszabb, ezért folytonossági meggondolások alapján kell, hogy legyen (egyetlen) olyan $\alpha$ paraméterérték, melyre $E_{1} F_{1}$ élhossza pontosan egységnyi. Így $\alpha$ értékének egy jó közelítését megkereshetjük intervallumfelezési eljárással úgy, hogy az $E_{1} F_{1}$ élhossz az egységtől legfeljebb adott hibakorláton belül essen, persze a szoftveres korlátokat is figyelembe véve.

A paraméteres poliédermodellt GeoGebrával és Cabri 3D szoftverrel is elkészítettük (ld. [5], [7]). Mindkét szoftvernél meg lehetett mérni az $E_{1} F_{1}$ élhosszt nagy pontossággal. Az $\alpha$ szög értékét GeoGebra esetében csúszkával vettük fel, ahol a lépésköz befolyásolta az egérrel történő grafikus paraméterbeállítás finomságát, de parancssorban bármilyen paraméterértéket fel lehetett vinni, így az intervallumfelezésnél nagy pontosságot (14 tizedesjegynyit) lehetett elérni nem túl sok lépésben. A Cabri 3D szoftver esetében egy köríven mozgó pont befolyásolta a szög nagyságát, itt 2 tizedesjegynyi pontosságot lehetett elérni. 


\section{További nemszerkeszthető Johnson-poliéderek modellezése}

Ebben a fejezetben vázlatosan ismertetjük a J84, J85, J87, J89, J90 nemszerkeszthető Johnson-poliéderek számítógépes modellezésének menetét, valamint a J89 Johnson poliéder (amely valószínűleg nem szerkeszthető, amint azt a 3. fejezetben részleteztük) számítógépes modellezésének a menetét is. Ezeket a modelleket is GeoGebrával és Cabri 3D szoftverrel készítettük el (ld. [5], [7]).

A kibővített sphenocorona (J87) modellje (ld. 5. ábrát) úgy készül, hogy a sphenocorona (J86) poliédermodell egyik négyzetlapját 4 darab szabályos háromszöglappal kicseréljük úgy, hogy konvex poliédert kapjunk (szemléletesen: egy négyzet alapú szabályos gúlával kiegészítjük a J86 poliéder modelljét).
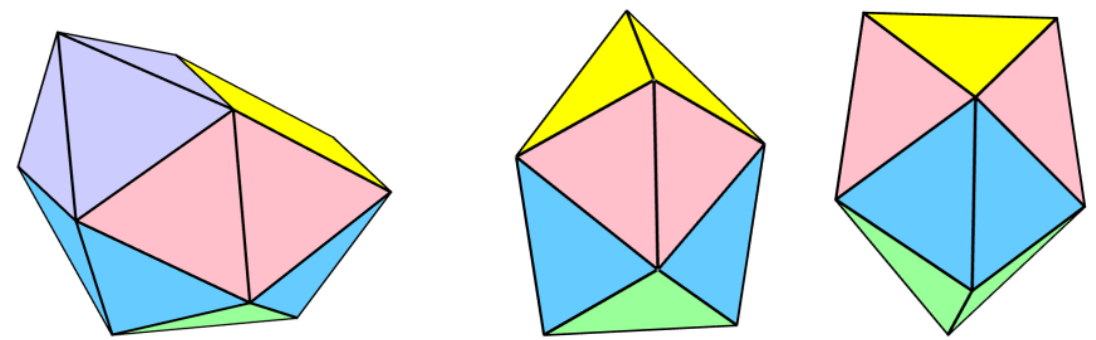

5. ábra. Kibővített sphenocorona (J87) egy nézete, és pisze disphenoid (J84) két nézete

Egy konvex poliéder két élét antipodálisnak (más szóval „átellenesnek”) nevezzük, ha létezik két olyan párhuzamos sík, melyek közrezárják a poliédert, a belsejébe nem metszenek bele, és a két élből egyet-egyet a párhuzamos síkpár különböző elemei tartalmaznak.

A pisze disphenoid (J84) paraméteres modelljében két szomszédos egységnyi élhosszú szabályos háromszöglap ( $A_{1} A_{2} B_{1}$ és $\left.A_{1} A_{2} C_{1}\right)$ hajlásszögét választjuk a modell $\alpha$ paraméterének. A modellben a két háromszöglap közös $A_{1} A_{2}$ éle lesz az egyik olyan él, amely 4 fokszámú csúcsokat köt össze (azaz 4-4 él fut össze az él végpontjaiban). A többi csúcsot (amelyek a $D_{1}, D_{2}, E_{1}, F_{1}$ pontok) gömbhármasok metszéspontjaiként szerkeszthetjük meg, a J86 poliéder modelljének ugyanilyen jelölésü csúcsaihoz hasonlóan. Ebben a modellben az élek közül egyedül az $A_{1} A_{2}$ éllel átellenes $E_{1} F_{1}$ él hossza változó. Az 5. ábrán két nézete is látható a J84 poliédernek (a csúcsok felcímkézése helyett a lapok színkódolását választottuk: sárga, rózsaszín, kék sorrendben készíthetők el a lapok az újabb és újabb csúcsok megszerkesztése után, a végén a zöld lapok közrezárt élének hossza függ az $\alpha$ paramétertől, azt kell beállítani megfelelően a J84 Johnson-poliéder modelljének elkészítéséhez). A soron következő Johnsonpoliéderek ábráinál is hasonló színkódolást használtunk.

A sphenomegacorona (J88) paraméteres modellje nagyon hasonlón készül a J86 poliéderéhez: a két szomszédos egységnyi élhosszú négyzetlap hajlásszögét választjuk a modell $\alpha$ paraméterének. A $B_{1}, A_{1}, C_{1}$ és $B_{2}, A_{2}, C_{2}$ csúcsok ugyanúgy a négyzetlapok csúcsai, és $D_{1}, D_{2}$ ugyazon gömbhármasok metszéspontjai. A $B_{1}, D_{1}, C_{1}$, és $B_{2}, D_{2}, C_{2}$ csúcsokhoz tartozó gömbhármasok metszéspontjai legyenek $E_{1}$ és $E_{2}$. A $D_{1}, B_{1}, B_{2}$, és $D_{1}, C_{1}, C_{2}$ csúcsokhoz tartozó gömb-hármasok metszéspontjai legyenek $F_{1}$ és $G_{1}$. Az élek közül egyedül az $A_{1} A_{2}$ éllel átellenes $F_{1} G_{1}$ él hossza változó a modellben. 

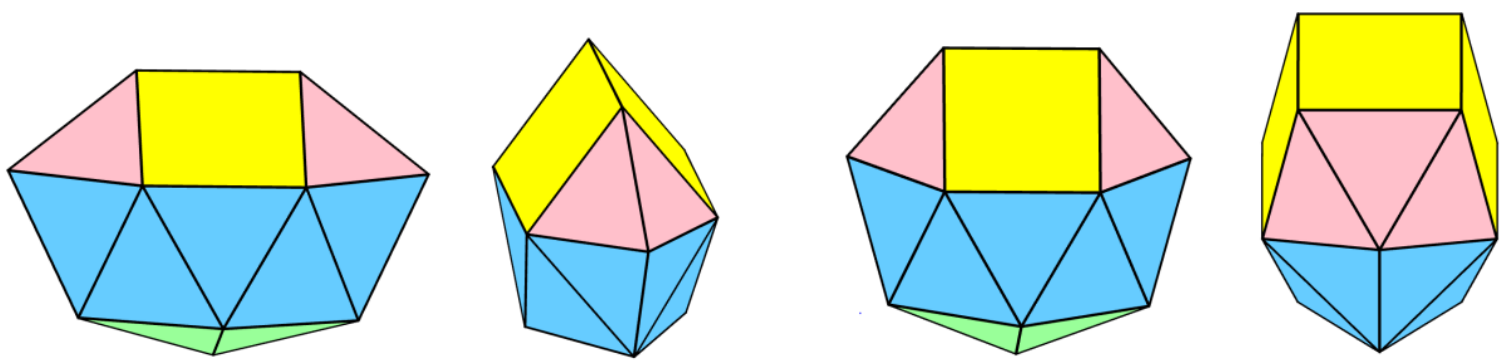

6 ábra. Sphenomegacorona (J88) két nézete, és hebesphenomegacorona (J89) két nézete

A hebesphenomegacorona (J89) paraméteres modelljében három egységnyi élhosszú négyzetlap csatlakozik egymáshoz, a középsővel zárjon be a két szélső $\alpha$ szöget. A többi csúcs megfelelő gömbhármasok metszéspontjaként állítható elő. Az élek közül egyedül a középső négyzetlappal párhuzamos, négyzetlapokra nem illeszkedő él hossza változó a modellben.
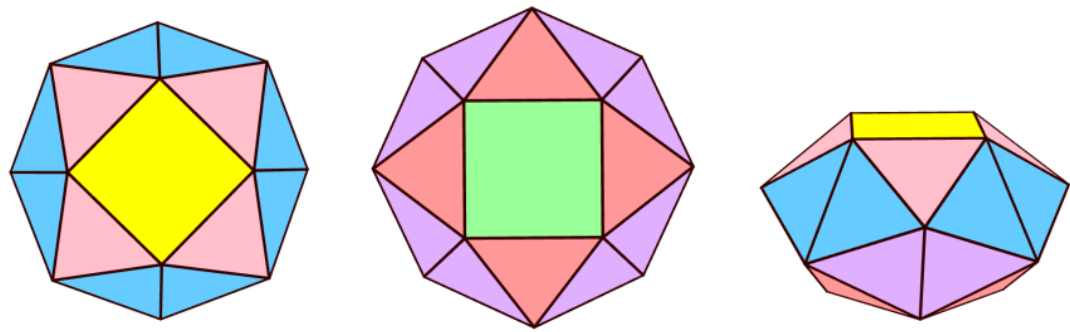

7. ábra. Pisze négyzetes antiprizma (J85) három nézete

A pisze négyzetes antiprizma (J85) modelljében egy egységnyi élhoszú négyzetlapjával $\alpha$ szöget zárjon be a hozzá közös éllel csatlakozó 4 darab szabályos háromszöglap mindegyike. A többi csúcs megfelelö gömbhármasok metszéspontjaként állítható elő. Az átellenes négyzetlap csúcsai kerülnek utoljára megszerkesztésre, e négyzetlap oldalhossza változó, a többi él egységnyi hosszú a modellben.
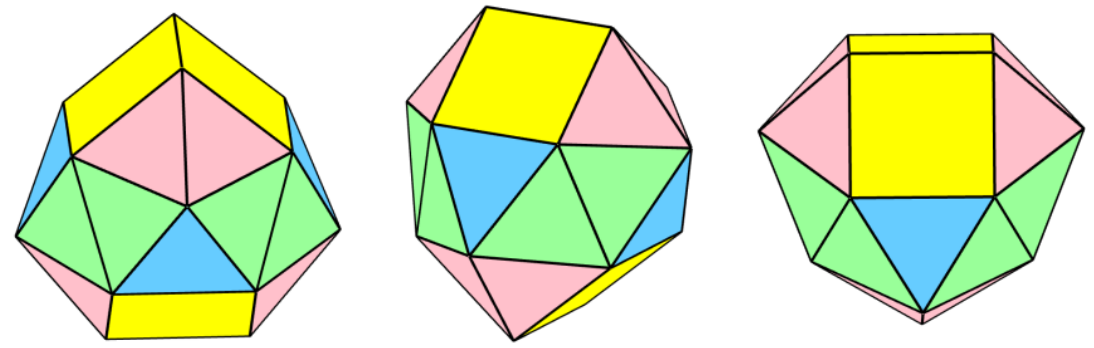

8. ábra. Disphenocingulum (J90) három nézete

A disphenocingulum (J90) két, egységnyi hosszú négyzetlap-párja $\alpha$ szöget zárjon be, majd a két négyzetlap mindegyikéhez csatlakozó élek átellenes csúcsai kerüljenek megszerkesztésre, végül ezt a két különálló részt úgy toljuk el a közös szimmetriatengelyük irányában, hogy a négyzetlapokra illeszkedő és a két részt összekötő (a 8. ábrán kék) háromszögek szabályosak legyenek. Ekkor marad 4 egyenlö hosszú él a modellben, amely változó hosszú.

Végezetül megjegyezzük, hogy a pisze kocka és pisze dodekaéder arkhimédészi testek úgy modellezhetők egy paraméteres modellel, hogy adott forgatási szög esetén megszerkeszthető az az eltolási távolság, hogy az eltolt, majd elforgatott négyzet- ill. ötszöglapokat egyenlő hosszúságú élek kössék össze (ennek megszerkesztéséhez az egyik elforgatott lap élének felezőmerőleges síkját kell elmetszeni egy szomszédos elforgatott lap megfelelő csúcsára illesztett eltolási vektor irányú egyenessel). 

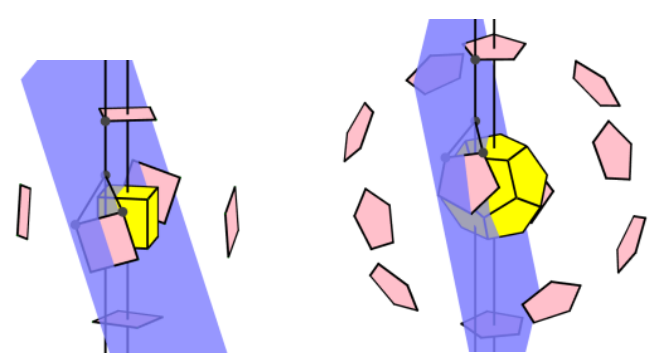

9. ábra. Pisze kocka és pisze dodekaéder modelljének szerkesztése
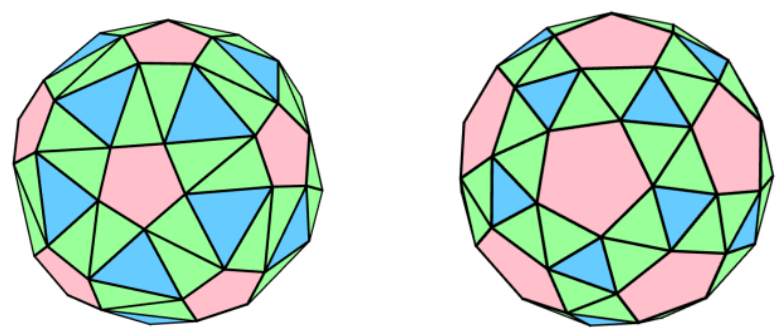

10. ábra. Pisze dodekaéder paraméteres modellje a paraméter értékének beállítása előtt és után

\section{Oktatási tapasztalat}

Az Óbudai Egyetem Ybl Miklós Építéstudományi Karán oktatott „Számítógépes térgeometriai modellezés" kurzus egyik témaköre a poliéderek modellezése. A tapasztalatok alapján a hallgatóknak megfelelö ismereteik vannak az alaptestekröl (hasáb, gúla) és a szabályos testekről. De további konvex és nem konvex poliéderekről, vagy azok tulajdonságairól az ismereteik elég hiányosak. A geometriai módszereket szívesen alkalmazzák számítógépes modellezés során, és kedvelik a mozgó vagy mozgatható modelleket. Amint a hallgatók rájöttek, hogy hogyan lehet három gömb metszéspontjaként újabb és újabb csúcsok megszerkesztésével elkészíteni az itt ismertetett nem négyzetes forgásszimmetriájú paraméteres poliédermodelleket, szívesen dolgozták ki ezeket. Elnyerte a tetszésüket, hogy mindenféle matematikai számítások nélkül, elég pontos számítógépes modellt lehetett így készíteni ezekről az érdekes alakú Johnson-poliéderekről.

\section{Köszönetnyilvánítás.}

Szeretném megköszönni Németh Lászlónak, hogy lehetőséget biztosított ennek a kéziratnak a megjelentetéséhez a Dimenziók - Matematikai közlemények 2020-as kötetében.

\section{Irodalomjegyzék}

[1] Alison, N., Polyhedra Viewer, https://polyhedra.tessera.li/

[2] Archimedean solid, Wikipedia, https://en.wikipedia.org/wiki/Archimedean_solid

[3] Archimedean Solid, Wolfram Mathworld, https://mathworld.wolfram.com/ArchimedeanSolid.html

[4] Bancsik Zs., Lajos S., Juhász I., Ábrázoló geometria kezdőknek, Debreceni Egyetem, 2004., https://gyires.inf.unideb.hu/mobiDiak/Juhasz-Imre/Abrazolo-geometria-kezdoknek/abrazologeometria.pdf

[5] Cabri 3D, https://cabri.com/en/enterprise/cabri-3d/

[6] Cox, D. A., Galois Theory, Wiley, Hoboken, NJ, 2012.

[7] GeoGebra, https://www.geogebra.org/

[8] Johnson solid, Wikipedia, https://en.wikipedia.org/wiki/Johnson_solid

[9] Kovács, Z., Geometria szerkesztések I. (Euklidészi szerkesztések), Debreceni Egyetem Matematikai és Informatikai Intézete, Debrecen (2001), pp. 23., http://zeus.nyf.hu/ kovacsz/szerk.pdf

[10] The Johnson solids, Eusebeia, http://eusebeia.dyndns.org/4d/johnson 